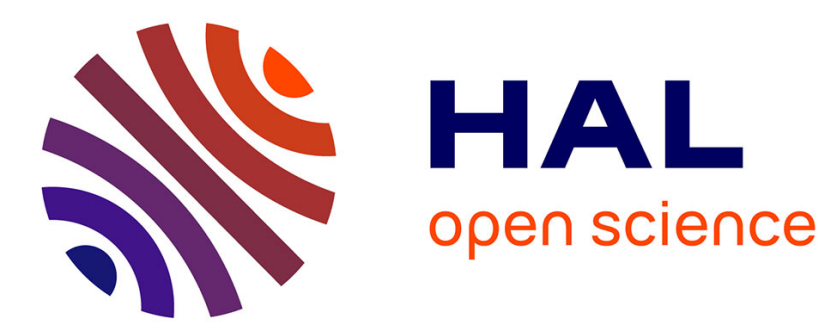

\title{
Migration and Cross-Border Financial Flows
}

Maurice Kugler, Oren Levintal, Hillel Rapoport

\section{To cite this version:}

Maurice Kugler, Oren Levintal, Hillel Rapoport. Migration and Cross-Border Financial Flows. 2015. halshs-01134465

\section{HAL Id: halshs-01134465 \\ https://shs.hal.science/halshs-01134465}

Preprint submitted on 24 Mar 2015

HAL is a multi-disciplinary open access archive for the deposit and dissemination of scientific research documents, whether they are published or not. The documents may come from teaching and research institutions in France or abroad, or from public or private research centers.
L'archive ouverte pluridisciplinaire HAL, est destinée au dépôt et à la diffusion de documents scientifiques de niveau recherche, publiés ou non, émanant des établissements d'enseignement et de recherche français ou étrangers, des laboratoires publics ou privés. 


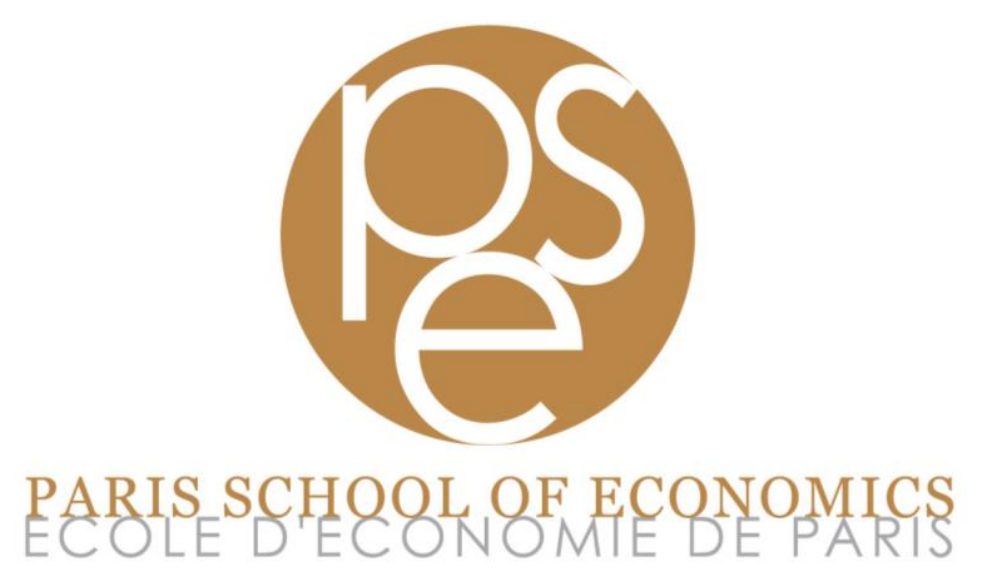

Migration and Cross-Border

Financial Flows

Maurice KUGLER

UNDP
Oren LEVINTAL

Interdisciplinary Center Herzliya

(IDC), School of Economics
Hillel RAPOPORT

Paris School of Economics,

University Paris 1 P-S

Department of Economics,

Bar-Ilan University

March 2015

\section{G-MonD}

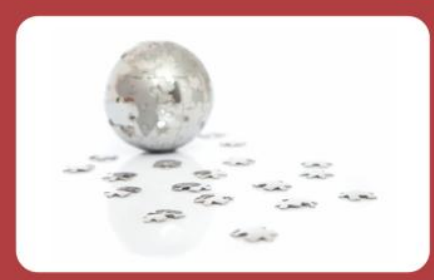

Working Paper $n^{\circ} 40$

For sustainable and inclusive world development 


\title{
Migration and Cross-Border Financial Flows*
}

\author{
Maurice Kugler ${ }^{\mathrm{a}}$, Oren Levintal ${ }^{\mathrm{b}}$, and Hillel Rapoport ${ }^{\mathrm{c}, \mathrm{d}}$ \\ ${ }^{\mathrm{a}} \mathrm{UNDP}$ \\ ${ }^{\mathrm{b}}$ Interdisciplinary Center Herzliya (IDC), School of Economics \\ ${ }^{c}$ Paris School of Economics, University Paris 1 Pantheon-Sorbonne \\ ${ }^{\mathrm{d}}$ Department of Economics, Bar-Ilan University
}

March 2015

\begin{abstract}
The gravity model has provided a tractable empirical framework to account for bilateral flows not only of manufactured goods, as in the case of merchandise trade, but also of financial flows. In particular, recent literature has emphasized the role of information costs in preventing larger diversification of financial investments. This paper investigates the role of migration in alleviating information imperfections between home and host countries. We show that the impact of migration on financial flows is strongest where information problems are more acute (that is, for more informational sensitive investments, between culturally more distant countries, and when the source country of migrants is a developing country) and for the type of migrants that are most able to enhance the flow of information on their home country, namely, skilled migrants. We interpret these differential effects as additional evidence pointing to the role of information in generating home-bias and as new evidence of the role of migration in reducing information frictions between countries.
\end{abstract}

Keywords: Migration, international financial flows, international loans, gravity models, information asymmetries

JEL classification: F21, F22, O1.

\footnotetext{
*This paper was initiated as part of a project on "Migration, International Capital Flows and Economic Development" based at the Harvard Center for International Development and funded by the MacArthur Foundation's Initiative on Global Migration and Human Mobility. See Kugler and Rapoport (2011a) for an early version focusing on equity portfolio flows. Hillel Rapoport acknowledges support from Cepremap. Address for correspondance: Oren Levintal: oren.levintal@idc.ac.il. Hillel Rapoport: hillel.rapoport@psemail.eu. Maurice Kugler: maurice.kugler@gmail.com.
} 


\section{Introduction}

Previous literature has emphasized the role of gravity forces in determining the pattern of international financial flows. A key role in this literature is assigned to informational frictions. Gravity variables that affect the extent of such frictions (e.g., lower distance, common language, common legal origin, etc.) have consistently been shown to increase bilateral financial flows and mitigate home bias (Coeurdacier and Rey, 2013). Portes and Rey (2005) and Lane and Milesi-Ferretti (2008) show this for cross-border equity flows. Aviat and Coeurdacier (2007) extend the analysis to bank loans, equity flows and bond holdings. ${ }^{12}$

This paper posits that the cross-border movement of people reduces informational frictions across countries and stimulates bilateral financial flows. This is due to the fact that migration from country $j$ to country $i$ has the potential to reveal information on country $j$ which is valuable for investors in country $i$ (e.g., information on the characteristics of the home country's financial and political institutions). In addition, migrants may create or integrate into international business and financial networks, thereby enhancing financial transactions between their home and host countries. Our paper follows a growing literature demonstrating the role of migration in facilitating trade (Gould, 1994, Head and Ries, 1998, Rauch and Trindade, 2002, Rauch and Casella 2003, Combes et al., 2005, Iranzo and Peri, 2009, Parsons and Vezina, 2014),

\footnotetext{
${ }^{1}$ In a recent theoretical contribution, Okawa and van Wincoop (2012) derive conditions under which the gravity model is well suited to analyze financial flows. In particular, information frictions should affect asset return volatility (and not the mean); global shocks cannot be hedged; and there are no borrowing constraints.

${ }^{2}$ Historical perspectives are provided by Chitu, Eichengreen and Mehl (2014) and Flandreau (2006).
} 
FDI (Kugler and Rapoport, 2007, 2011, Javorcik et al., 2011), and the diffusion of knowledge (Kerr 2008, Agrawal et al., 2011)³.

We test the hypothesis that migration affects international financial flows. Therefore we introduce migration into an otherwise standard gravity model of financial flows, following Martin and Rey (2004) and Aviat and Coeurdacier (2007). As a general proposition, we expect the effect of migration on financial flows to be larger where informational imperfections are more pervasive. This is supposedly the case for long term versus short term investments, or for country pairs that differ in terms of cultural proximity. The effect of migration should also depend on migrants' skills. In particular, highly educated migrants are more likely to be part of international business and financial networks and, hence, likely more able to transfer information and reduce bilateral transaction costs. Hence, we expect their impact on financial flows to be larger.

Our empirical strategy relies on the estimation of differential effects along a number of dimensions: a skill dimension, a cultural dimension, and an asset-type dimension. We start by showing that migration has a significant positive impact on international bank loans. When we distinguish between skilled and unskilled migrants, we find a significantly stronger impact for skilled migration. For example, when we introduce skilled and unskilled migrants jointly to a gravity model of international bank loans, we find a significant positive elasticity of skilled migrants of about 0.2 while no significant effect is found for unskilled migrants. We take this result as initial supportive evidence of our conjectures.

\footnotetext{
${ }^{3}$ See Docquier and Rapoport (2012) for a recent survey of this literature.
} 
To rule out the possibility that our results reflect effects that go from migration to trade and from trade to financial flows we conduct a placebo experiment. Specifically, we estimate a differential effect of skilled versus unskilled migrants on exports. While such heterogeneous effects are present in the case of financial flows, they are absent in the case of trade. This result confirms that the differential effect on financial flows is not driven by trade.

Next, we allow for the effect of migration to vary with the degree of cultural proximity. We find that the effect of migration is nearly zero for country pairs that share common language, colonial history or legal origin, and positive otherwise. These results are consistent with the view that the potential for migration to alleviate informational frictions is higher for culturally distant countries. We run the same regressions on trade, as a placebo test, and find that overall the differential effect across cultural proximity is specific to financial flows and not trade.

Most importantly in our view, we are able to distinguish between foreign investments in long versus short term bonds. Arguably, the longer term to maturity of the former makes them riskier and more information sensitive. We find that the effect of migration on investment in long term bonds is indeed significantly stronger compared to short term bonds. Actually, for short term bonds we do not find a significant effect of migration, whereas the elasticity of investment in long term bonds with respect to migration is positive, significant and economically meaningful at $0.14-0.16$, depending on specification.

Finally, we also expect the effect of migration to have the greatest potential where information imperfections are more pervasive, that is, in developing countries. 
And indeed, when we interact our migration variables with a dummy for developing country status, we find a magnified effect coming mostly from the extensive margin. This suggests that the role of migrants in promoting financial inflows to developing countries goes well beyond remittances (Aggrawal et al., 2011, Guiliano and RuizArranz, 2009).

Taken together, these differential effects are fully in line with the theoretical arguments outlined above and provide supportive evidence that migration contributes to lower informational frictions across countries. The main concern in this analysis is the possibility of omitted variables governing the joint pattern of emigration and reverse financial flows. However, to be able to explain the entire set of results, a possible confounder should explain not just the main effect but also the differential effects for skilled versus unskilled migrants, culturally close versus distant countrypairs, and long versus short-term bonds, as well as the time structure of our results. We find the existence of such a variable unlikely.

\section{Methodology}

Our main assumption is that financial investments are informational sensitive. In other words, investors tend to invest more in places they know better. The well known implication of this assumption is the home bias in financial flows, which has been found repeatedly in the literature (Coeurdacier and Rey, 2013). Given these information frictions, the presence of migrants is expected to stimulate bilateral financial flows. Specifically, migrants facilitate the flow of information from their 
home countries to their host countries.

We build on the gravity model developed by Okawa and van Wincoop (2012). In particular, we assume that investors in foreign markets perceive higher volatility of asset returns compared to domestic markets. This assumption gives rise to a gravity equation where the log of bilateral financial flows depends on the log of information frictions. ${ }^{4}$ Information frictions depend on a set of bilateral variables such as distance, common language etc. We test the hypothesis that the information frictions between country $i$ and country $j$ are alleviated by migration from country $j$ to $i$. In particular, we posit that migrants from country $j$ that live in country $i$ convey important information about country $j$ to investors in country $i$. This information enables to reduce the risk and enhance financial investments from country $i$ to country $j$.

A simple gravity model is likely to suffer from an omitted variable bias. Hence, we focus our analysis on differential effects across a number of dimensions. The first dimension is the general level of education of the migrants. To become involved in the financial sector, migrants need to have high cognitive skills. First, they are expected to have deep knowledge about their home country economy and be able to gain new knowledge constantly. Second, they need to be able to exchange this knowledge with the financial sector of their host country in a credible way. This task requires high communication skills. Third, skilled migrants are more likely to

\footnotetext{
${ }^{4}$ Okawa and van Wincoop (2012) show that this specification also depends on the assumptions that investors can fully hedge against global or regional shocks and that there are no borrowing constraints. To the extent that these assumptions do not fully hold in our context, we view the gravity model as an approximation of the true model. In this case, our identification depends on the accuracy of the gravity model as an approximation of the true model.
} 
serve as liaison agents, or reference, and allow for reaching out to the business and financial community in their home country. Hence, the migration effect is likely to be stronger when migrants are more skilled. We test this differential effect by the following regression:

$$
\begin{aligned}
\log \left(\text { Loans }_{i j}\right)= & \alpha_{1} \log \left(\text { Skilled Migrants }_{i j}\right)+\alpha_{2} \log \left(\text { Unskilled Migrants }_{i j}\right) \\
& +\alpha_{3} \log \left(\text { Distance }_{i j}\right)+\alpha_{4} X_{i j}+c_{i}+c_{j}+\epsilon_{i j}
\end{aligned}
$$

Loans $_{i j}$ denotes the stock of international bank loans from country $i$ to country $j$ as of 2000. Skilled Migrants ${ }_{i j}$ is the stock of skilled migrants (i.e., with college education) from origin country $j$ living in destination country $i$, and Unskilled Migrants ${ }_{i j}$ refers to unskilled migrants (i.e., with below-college education). Hence, our first empirical test is to estimate the differential effect of skilled-unskilled migration from country $j$ to country $i$ on financial flows in the reverse direction, namely, from country $i$ to country $j$. The regression controls for the distance between the two countries as well as for other variables that are associated with cultural and economic proximity, denoted collectively by $X_{i j}$, as well as for origin and destination-country fixed effects, which are denoted by $c_{i}$ and $c_{j}$.

The second dimension that we exploit is the cultural proximity between the two countries. Since migrants alleviate informational frictions, their impact on financial flows should be strongest for country pairs that exhibit high informational frictions. For instance, migrants are likely to have a stronger impact on financial flows between 
the US and Egypt than between the US and Canada, simply because informational frictions in the latter case are very weak. We test this dimension by the following regression:

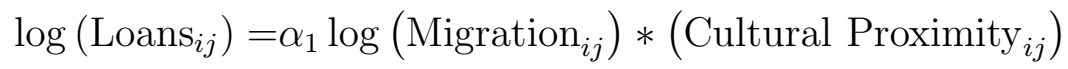

$$
\begin{aligned}
& +\alpha_{2} \log \left(\text { Migration }_{i j}\right)+\alpha_{3} \log \left(\text { Cultural Proximity }{ }_{i j}\right) \\
& +\alpha_{4} \log \left(\text { Distance }_{i j}\right)+\alpha_{5} X_{i j}+c_{i}+c_{j}+\epsilon_{i j}
\end{aligned}
$$

Here, Cultural Proximity is an indicator for the cultural proximity of countries $i$ and $j$, e.g. common language, colonizer and legal origin. Our hypothesis is that migration should have a stronger effect on financial flows between countries that are culturally more distant. We test this hypothesis in section 4.2. As explained, we also expect stronger effects when the migrants' home-country is a developing country and in a last set of regressions we interact our variable of interest with a non-OECD dummy.

Finally, we also look at differences between different securities. Specifically, we test the migration impact on investment in long term versus short term bonds. Our hypothesis, which is supported by external data, is that apart from term to maturity, long term bonds and short term bonds are relatively similar along other dimensions (see Table 5). The difference in the term to maturity imposes a difference in informational sensitivity. In particular, long term bonds are likely to be more informational sensitive than short term bonds, because they require to forecast economic conditions 
on a longer horizon, meaning that uncertainty is increased. This excess informational friction of long term bonds relative to short term bonds can be alleviated by migrants. Hence, the migration effect should be stronger for long term bonds relative to short term bonds. We test this hypothesis by comparing the two regressions:

$$
\begin{aligned}
& \log \left(\text { Long term debt } \mathrm{dij}_{i j}\right)=\alpha_{1} \log \left(\text { Migration }_{i j}\right)+\alpha_{2} \log \left(\text { Distance }_{i j}\right) \\
& +\alpha_{3} X_{i j}+c_{i}+c_{j}+\epsilon_{i j} \\
& \log \left(\text { Short term debt }_{i j}\right)=\alpha_{1} \log \left(\text { Migration }_{i j}\right)+\alpha_{2} \log \left(\text { Distance }_{i j}\right) \\
& +\alpha_{3} X_{i j}+c_{i}+c_{j}+\epsilon_{i j}
\end{aligned}
$$

The migration coefficient is expected to be larger in the first regression, because investment in long term debt is likely to be more informational sensitive than short term debt. This is shown in section 4.3.

To summarize, we estimate differential effects along three dimensions - skilled versus unskilled migrants, cultural proximity, and long versus short term bonds. These dimensions form the basis of our empirical strategy.

\section{Data}

The migration data come from Artuc, Docquier, Ozden and Parsons (2015) data set, the last extension of the Docquier and Marfouk (2006) dataset which includes bilateral data on migration by country of birth, skill category (skilled v. unskilled, 
the former having college education) and gender for 195 sending/receiving countries in 1990 and 2000. The main additional novelty is that the dataset now captures South-South migration based mainly on observations and occasionally on estimated data points (for the skill structure)..$^{5}$

Our financial data come from two commonly used sources. Data on international bank loans are from the Consolidated Banking Statistics published by the Bank of International Settlements (BIS). Our main specification refers to the year 2000, for which we have 17 lending countries, 175 borrowing countries and a total of 1,628 country pairs (observations) with positive loan values, given missing data. In addition, we take data on investment in short term bonds and long term bonds from the International Monetary Fund (IMF) in its Coordinated Portfolio Investment Survey (CPIS).

Our migration data includes two years, 1990 and 2000. Ideally, we would like to estimate a panel or a difference equation. However, since we only have two time periods, this is not possible. Moreover, the sample period is characterized by the formation of many new countries, mainly in Eastern Europe. These countries experienced strong outflows of migrants, and inflow of foreign investment to build these new economies. This phenomena introduces endogeneity to the sample, which is difficult to control for. Omission of these newly formed countries would exclude the main time variation in the stock of migrants during this period, which is also limiting for a panel analysis. For this reason, we choose to focus the analysis on the cross-section dimension of our data.

\footnotetext{
${ }^{5}$ See http://perso.uclouvain.be/frederic.docquier/filePDF/DMOP-ERF.pdf for further details.
} 
We construct a cross section that minimizes as much as possible endogeneity concerns. First, we take a lag of 10 years between the migration data and the financial data. Hence, we regress financial flows in 2000 on migration data in 1990. This way we reduce short term endogeneity, such as new countries that were established in the 1990s and experienced an outflow of migrants and an inflow of foreign investments.

Second, we choose as our benchmark results the regression of financial investments in 2000 on migration in 1990, though we also run similar regressions for 2010 financial data on 2000 migration data. The reason we focus on the earlier period is that our dataset indicates that many country pairs had no financial investments in the 1980s, and started their investment connections only in the 1990s. For instance, if we restrict our sample to 16 countries that were active in foreign lending in 1985, we obtain around 1,400 lending-borrowing country pairs between 1985 and 1992. The number of country pairs increased significantly during the 1990s and reached 1,877 by the end of the decade. By contrast, in the following decade there was no significant change in the number of country pairs. ${ }^{6}$ Part of the increase in lending-borrowing country pairs in the 1990s is due to new countries that were formed in the 1990s and part is due to a rise in the volume of international loans. In this respect, the migration stock in 1990 can be regarded as a predetermined variable for country pairs that had no lending activity in the 1980s and started to lend in the 1990s. ${ }^{7}$

We complete our dataset with gravity variables taken from Aviat and Coeurdacier (2007) and CEPII (CHELEM dataset). Trade data are taken from Feenstra et al. (2005).

\footnotetext{
${ }^{6}$ In 2010 the number of country pairs reached 1,908.

${ }^{7}$ However, our results are fully robust to the use of data for the $2000-2010$ period.
} 


\section{Results}

To relate our results to previous literature, we start with the specification of Aviat and Coeurdacier (2007) who studied a similar regression without the migration variable. After replicating their results, we proceed with a specification that is in line with Okawa and van Wincoop (2012). This specification includes country fixed effects of source and destination countries and excludes asset return variables. We estimate this specification with OLS and Poisson estimators, where the latter enables to include zero flows.

Table 1 presents the first set of results. Column (1) reports a gravity specification without country fixed effects, which replicates the first specification studied by Aviat and Coeurdacier (2007). ${ }^{8}$ To save space, the table reports only variables that are $i j$ specific. The results suggest that cross-border international loans tend to increase with physical and cultural proximity, as found previously by Aviat and Coeurdacier (2007) and Portes and Rey (2005). Overall, our estimated coefficients are consistent with Aviat and Coeurdacier (2007). For instance, the distance coefficient in Aviat and Coeurdacier (2007) is estimated at -0.44 (table 4 column 3 in their paper), which is statistically not different from our estimate.

We introduce migration in column (2) and find a strong positive effect of migration on international loans, with an elasticity of .18. Interestingly, the inclusion of migration reduces the coefficients of the traditional gravity variables (e.g., distance, colonial links, common language and common legal origin). This result suggests that

\footnotetext{
${ }^{8}$ The only difference is that Aviat and Coeurdacier (2007) imposed a coefficient of one on the log of GDP while we do not. However, since we concentrate in the main text on the specification with country fixed effects, this difference will be immaterial.
} 
the presence of foreign migrants helps alleviating information frictions that impede foreign lending. We explore this hypothesis further below.

The flow of migration between countries is not random. Some countries tend to attract more migrants than others (e.g., the US), or send more migrants to other countries (e.g., African countries). Hence, the main concern with the specification in column (2) is that the migration variable captures unobservable characteristics of the sending or receiving countries which are also correlated with financial flows. A first step to address this issue is to include country fixed effects. Columns (3) and (4), therefore, report the results with country fixed effects. The coefficient on migration is still highly significant; the other coefficients are generally robust to the inclusion of fixed effects, though some of them exhibit large changes in magnitude, in particular the distance variable.

Our preferred model follows the gravity specification of Okawa and van Wincoop (2012), which is consistent with information frictions that affect the perceived volatility of asset returns. Hence, we drop the fiscal variables, which represent transaction costs that do not affect the perceived volatility. We also drop stock market correlation, as suggested by Okawa and van Wincoop (2012). This does not affect much the explanatory power of the regression, as evident from the $R^{2}$ statistic. On the other hand, we gain a much larger sample with 17 lending countries, 175 borrowing countries and a total of 1,628 observations (country pairs), given missing data and zeros, which is twice the original sample size. For a list of countries included in this sample see Table 9. Moreover, by employing the Poisson estimator suggested by Santos Silva and Tenreyro (2006) we are able to include observations with zero 
loans, which raises the sample size to 1,827 observations. Note that we add only country pairs for which we positively know that the amount of loans is zero or close to zero. ${ }^{9}$ The Poisson estimator produces a smaller distance coefficient, as already emphasized by Santos Silva and Tenreyro (2006) in a trade regression. By contrast, the migration coefficient slightly increases (see Column 6) compared to the OLS estimator (see Column 5) and remains highly significant. However, the other covariates seem less robust to the estimation method, as their coefficients change significantly across the two estimators.

\subsection{Skilled versus unskilled migration}

As explained in section 2, our empirical strategy relies on differential effects along three dimensions: skilled versus unskilled, cultural proximity and information sensitivity. The significance of migration in the gravity regressions of foreign loans suggests that migrants indeed alleviate informational frictions between their host and home countries. Arguably, to be able to perform such a role, migrants should have the required skills and connections that allow them to communicate efficiently with the financial markets in their host country and connect them with their home countries. Hence, one would expect the migration effect to work mainly through skilled migrants. We test this hypothesis by comparing the coefficient of skilled migrants versus unskilled migrants in the gravity model.

\footnotetext{
${ }^{9}$ The rise in the sample size is moderate for two reasons, First, we include only country pairs that have positive migration flows. Second, countries that do not borrow from at least two lending countries are dropped due to the fixed effects. Hence, conditional on having positive migration and at least two lending countries per each borrowing country, the share of country pairs with zero loans is around 11 percent of the sample.
} 
Table 2 re-estimates the gravity model by distinguishing between skilled and unskilled migrants. Skilled migrants are defined as migrants with at least college education. The samples correspond to columns (5) and (6) of Table 1, subject to data availability. The results strongly indicate that the migration effect is driven primarily by skilled migrants, because only skilled migration is significant. This holds for the OLS as well as for the Poisson regressions.

\section{Placebo Test on Trade}

One may be concerned that the effect of migration on financial flows captured in our regressions may in fact be mediated through trade. Since migrants stimulate trade and trade affects financial flows (Aviat and Coeurdacier 2007), a correlation between migration and financial flows is expected even if there is no causal effect. However, to explain our differential effects for skilled v. unskilled migrants, it should be the case that skilled migration has a stronger effect on trade than unskilled migration, which is not what we find. Columns (2) and (4) in table 2 perform this placebo test. As can be seen, in the export regressions there is no differential effect for skilled migration. This replicates Kugler and Rapoport (2011b) who found a similar result on a much larger sample. This result implies that foreign loans are much more information sensitive than foreign trade.

\subsection{Cultural Proximity}

We next examine the migration effect on countries that are culturally close to each other compared to countries that are culturally distant. Our conjecture is that 
migration should have a stronger effect on financial flows between countries that are culturally more distant. We therefore add interaction terms between migration and cultural proximity variables, such as common language, common colonizer and common legal origin. We expect a negative coefficient on the interaction terms.

Tables 3 and 4 present the result with OLS and Poisson, respectively. The Poisson regressions show clearly that the migration effect is smaller for countries that are culturally closer one to the other. In fact, the results suggest that the migration effect is practically zero for countries that are culturally close. Hence, the presence of migrants is mostly critical to financial flows between countries that are culturally more distant. A similar picture arises from the OLS regressions (Table 3), though the results are somewhat weaker.

\section{Placebo Test on Export}

We run the placebo test on export, as we did previously. Specifically, we test whether the interaction of migration with cultural proximity is significant in trade regressions. The results are presented in tables 3 and 4 on the lower panels. Overall, the interactions are insignificant, particularly for the Poisson regressions. The OLS regressions suggest that there is some differential effect on exports, but it seems weaker than the effect on financial flows, and less robust (only in the interaction with common colonizer is significant). This placebo test indicates that the differential effect of migration on financial flows across different levels of cultural proximity reflects informational frictions that are stronger for financial flows than for exports. 


\subsection{Short versus Long term Debt}

In this section we test whether the migration effect differs across financial assets that vary in their information sensitivity. Namely, investment in financial assets that are riskier and require deeper knowledge about the destination country should be affected more strongly by the presence of migrants from the destination country.

To explore this point, we exploit data on international investment in long term and short term bonds. These two types of securities differ mainly in their term to maturity. To support this argument, we provide data on European bonds published by the ECB, which is summarized in Table 5 . These data show that 95 percent of short term bonds and long term bonds are issued by financial institutions and governments. Only 5 percent are issued by non-financial corporations. The table shows that long term bonds and short term bonds are fairly similar in terms of issuer's type. Moreover, almost all bonds are issued by borrowers that are relatively safe, namely, governments and financial institutions. ${ }^{10}$ This indicates that the heterogeneity in credit risk across long term and short term bonds is relatively narrow. While these data represent European Bonds, we do not have any reason to believe that it is dramatically different in other countries. Hence, we conclude that long term bonds and short term bonds reflect assets that are relatively homogeneous in terms of credit risk. Thus, the principal difference between long term and short term bonds is the term to maturity. ${ }^{11}$ We use this difference as a proxy for information sensitivity.

\footnotetext{
${ }^{10}$ It should be noted that our regressions refer to 2001 , hence the rise in default risk of banks and governments during the crisis of 2008 is not included in our sample period.

${ }^{11}$ Short term bonds are defined as bonds with maturity of up to one year.
} 
Investment in long term bonds requires a deeper understanding of the destination country. The investor needs to forecast credit risks on a longer horizon. Furthermore, if the bonds are not held to maturity, then interest rate risk is also involved. In most cases, exchange rate risk would also be an issue in international bond markets. Hence, investors in long term bonds need to have better knowledge not only on the credit risk of the particular issuer, but also on the macroeconomic environment of the destination country. This implies that investment in long term bonds is more informational sensitive than short term bonds. Hence, we can identify the migration effect by testing whether the migration coefficient is larger for long term bonds compared to short term bonds.

The results are presented in Table 6 . Since the sample size is small, we focus here on the Poisson estimator, which includes zero values (but not missing data). The list of countries included in this sample is given in Table 10. The main result that appears from the table is that migration is highly significant for long term bonds, but not significant for short term bonds. Note that distance is also much more significant for long term bonds, which is consistent with our assumption that these assets are riskier. Namely, investors are more reluctant to invest in risky assets in distant economies due to their lack of knowledge on these economies. These results indicate that the migration effect works through the information channel, because informationally sensitive investments are more affected by the presence of migrants. 


\section{Developed versus developing countries}

The migration effect is likely to be more pronounced for developing countries, where information imperfections are more pervasive. Migrants that move from these countries to other countries convey with them information on their origin countries that is otherwise hard to obtain. We test this hypothesis by adding interactions of the migration variable with a dummy variable for developing countries. ${ }^{12}$

Table 7 re-estimates the benchmark regression, by allowing the migration coefficient to vary across developed and non-developed countries. Here we see a difference between the OLS estimator and the Poisson estimator. While the OLS estimator shows positive though not statistically significant effects for the interaction, the Poisson estimator is positive and highly significant. Recall that the OLS estimator omits country pairs with zero value for the dependent variable (loans in this case). By contrast, the Poisson estimator accounts for the zero values. This suggests that the significance of the interaction in the Poisson regression is driven mainly by the extensive margin and less so by the intensive margin.

A similar result is obtained when we re-estimate the bond regressions (previously Table 6) by adding an interaction with a developing country dummy. The results are reported in Table 8. Again, the OLS estimator does not reveal any pattern across developed/non-developed countries, see columns (1) and (2). However, the Poisson estimator, presented in columns (3) and (4), shows clearly that investment in long-term bonds in a non-developed country is larger if the investing country hosts migrants from the non-developed country. Moreover, this effect is mute when we

\footnotetext{
${ }^{12}$ Developing countries are defined as non-OECD countries.
} 
look at short-term bonds, which we judge as less information sensitive than long term bonds. Hence, these results are consistent with our hypothesis that migrants enhance the flow of information across countries, which facilitates cross-border financial flows.

\section{Conclusion}

This paper investigates the role of migration as a determinant of international financial flows. We introduce migration into a standard gravity model and find a positive impact on financial flows. The results strongly suggest that the channel through which migration affects bilateral financial flows is the information channel. Indeed, we find that the effect of migration on financial flows is strongest where informational problems are more acute. This is the case when we compare asset types that differ in terms of informational sensitivity (e.g., short versus long term bonds), country pairs characterized by different levels of cultural proximity (e.g., countries sharing versus not sharing a common language), migrants' source countries characterized by more information imperfections (i.e., developing countries) and types of migrants that differ in their ability to disseminate information across borders (e.g., high-skill versus low-skill migrants). Overall, our results suggest that migration contributes to reduce home bias and information frictions across countries. This is a contribution that had not been documented before in the literature. In the particular case of developing countries, this also suggests that the role of migrants in promoting financial inflows to their home countries goes well beyond remittances (Aggrawal et al., 2011, Guiliano and Ruiz-Arranz, 2009). 


\section{References}

[1] Aggarwal, R., A. Demirgüç-Kunt, and M.S. Martínez Pería, "Do remittances promote financial development?", Journal of Development Economics, 96 (2011), 255-264.

[2] Agrawal, A.K, Kapur, D., J. McHale and A. Oettl, "Brain drain or brain bank? The impact of skilled emigration on poor country innovation", Journal of Urban Economics, 69 (2011), 43-55.

[3] Artuc, E., F. Docquier, C. Ozden and C. Parsons, "A Global Assessment of Human Capital Mobility: the Role of non-OECD Destinations", World Development, 65 (2015), 6-26.

[4] Aviat, Antonin and Nicolas Coeurdacier, "The geography of trade in goods and asset holdings," Journal of International Economics 71 (2007) 22-51.

[5] Chitu, Livia Barry Eichengreen and Arnaud J. Mehl (2014), "History, Gravity and International Finance," Journal of International Money and Finance.

[6] Coeurdacier, Nicolas and Helene Rey, "Home Bias in Open Economy Financial Macroeconomics," Journal of Economic Literature, 51(1), 2013, 63-115.

[7] Combes, P.-Ph., Lafourcade, M., and Mayer, T. (2005), "The trade creating effects of business and social networks: Evidence from France,' Journal of International Economics, 66, 1: 1-29. 
[8] Docquier, F. and A. Marfouk (2006), "International migration by education attainment, 1990-2000,' In C. Ozden and M. Schiff, eds.: International Migration, Brain Drain and Remittances, New York: McMillan and Palgrave, Chapter 5, pp. 151-99.

[9] Docquier, F. and H. Rapoport (2012): Globalization, brain drain and development, Journal of Economic Literature, 50(3), 681-730.

[10] Feenstra, Robert C., Robert E. Lipsey, Haiyan Deng, Alyson C. Ma, Hengyong Mo (2005), "World Trade Flows: 1962-2000," NBER Working Paper 11040.

[11] Flandreau, Marc, "Home Biases, Nineteenth Century Style," Journal of the European Economic Association, 4(2-3), 2006, 634-643.

[12] Guiliano, P. and M. Ruiz-Arranz (2009): Remittances, financial development, and growth, Journal of Development Economics, 90(1): 144-152.

[13] Gould, D.M. (1994), "Immigrant links to the home country: empirical implications for U.S. bilateral trade flows,' Review of Economics and Statistics, 76, 2: 30216.

[14] Head, K. and J. Ries (1998), "Immigration and trade creation: Evidence from Canada," Canadian Journal of Economics, 31, 1: 47-62.

[15] Iranzo, S. and G. Peri (2009): Migration and trade: theory with an application to the Eastern-Western European integration, Journal of International Economics, 79, 1: 1-19. 
[16] Javorcik, B.S., C. Ozden, M. Spatareanu and I.C. Neagu (2011): Migrant Networks and foreign Direct Investment, Journal of Development Economics, 94, 2: 151-90. 13

[17] Kerr, W.R. (2008): Ethnic Scientific Communities and International Technology Diffusion, Review of Economics and Statistics, 90: 518 - 537.

[18] Kugler, M., and H. Rapoport (2007), "International labor and capital flows: complements or substitutes?,' Economics Letters, 94(2): 155-62.

[19] Kugler, M., and H. Rapoport (2011a), "Migration and cross-border equity portfolio flows,' CID Working Paper No. 223, Harvard University, July.

[20] Kugler, M., and H. Rapoport (2011b), "Migration, FDI and the margins of trade,' CID Working Paper No 222, Harvard University, June.

[21] Lane, Philip R., and Gian Maria Milesi-Ferretti, "International Investment Patterns,' Review of Economics and Statistics, 90:3 (2008), 538-549.

[22] Martin, Philippe, and Helene Rey, "Financial Super-Markets: Size Matters for Asset Trade,' Journal of International Economics 64:2 (2004), 335-361.

[23] Okawa, Yohei and Eric van Wincoop (2012), "Gravity in International Finance," Journal of International Economics 87 (2012), 205-215.

[24] Parsons, C. and P.-L. Vezina (2014): Migrant networks and trade: the Vietnamese boat people as natural experiment, Mimeo., Oxford University. 
[25] Portes, Richard, and Helene Rey, "The Determinants of Cross-Border Equity Flows,' Journal of International Economics 65:2 (2005), 269-296.

[26] Rauch, J.E. and A. Casella (2003): Overcoming informational barriers to international resource allocation: prices and ties, Economic Journal, 113: 2142.

[27] Rauch, J.E. and V. Trindade (2002): Ethnic Chinese networks in international trade, Review of Economics and Statistics, 84, 1: 116-30.

[28] Santos Silva, J. M. C. and Silvana Tenreyro (2006), "The Log of Gravity," The Review of Economics and Statistics, November 2006, 88(4): 641-658. 
Table 1: International bank lending and migration

\begin{tabular}{|c|c|c|c|c|c|c|}
\hline \multirow[t]{2}{*}{ Dependent Variable: } & \multicolumn{5}{|c|}{$\log \left(\operatorname{Loans}_{i j}\right)$} & \multirow{2}{*}{$\begin{array}{c}\text { Loans }_{i j} \\
\quad(6)\end{array}$} \\
\hline & (1) & $(2)$ & & (4) & (5) & \\
\hline \multirow{2}{*}{$\log$ Migration $_{i j}$} & & $0.184^{* * *}$ & & $0.125^{* *}$ & $0.150^{* * *}$ & $0.179^{* * *}$ \\
\hline & & $(0.038)$ & & $(0.050)$ & $(0.037)$ & $(0.028)$ \\
\hline \multirow[t]{2}{*}{$\log$ Distance $_{i j}$} & $-0.368^{* * *}$ & $-0.247^{* * *}$ & $-0.710^{* * *}$ & $-0.595^{* * *}$ & $-0.701^{* * *}$ & $-0.253^{* * *}$ \\
\hline & $(0.078)$ & $(0.080)$ & $(0.121)$ & $(0.123)$ & $(0.107)$ & $(0.050)$ \\
\hline \multirow{2}{*}{$(\text { Colonial Link })_{i j}$} & $0.897^{* * *}$ & $0.777^{* * *}$ & $1.337^{* * *}$ & $1.169^{* * *}$ & $1.328^{* * *}$ & 0.176 \\
\hline & $(0.239)$ & $(0.239)$ & $(0.266)$ & $(0.267)$ & $(0.204)$ & $(0.170)$ \\
\hline \multirow{2}{*}{$(\text { Language })_{i j}$} & 0.320 & 0.075 & 0.127 & 0.048 & 0.260 & -0.197 \\
\hline & $(0.202)$ & $(0.216)$ & $(0.187)$ & $(0.190)$ & $(0.160)$ & $(0.236)$ \\
\hline \multirow[t]{2}{*}{$(\text { Legal origin })_{i j}$} & $0.694^{* * *}$ & $0.579^{* * *}$ & $0.485^{* * *}$ & $0.410^{* * *}$ & 0.144 & $0.450^{* * *}$ \\
\hline & $(0.109)$ & $(0.117)$ & $(0.124)$ & $(0.117)$ & $(0.111)$ & $(0.121)$ \\
\hline \multirow[t]{2}{*}{$(\text { Fiscal Treaty })_{i j}$} & $0.009^{*}$ & 0.007 & 0.001 & -0.001 & & \\
\hline & $(0.005)$ & $(0.005)$ & $(0.004)$ & $(0.004)$ & & \\
\hline \multirow[t]{2}{*}{$(\text { Dividend Tax })_{i j}$} & -0.012 & -0.015 & $-0.022^{*}$ & $-0.024^{* *}$ & & \\
\hline & $(0.011)$ & $(0.011)$ & $(0.011)$ & $(0.011)$ & & \\
\hline \multirow[t]{2}{*}{$(\text { Interest Tax })_{i j}$} & -0.014 & -0.014 & 0.013 & 0.013 & & \\
\hline & $(0.012)$ & $(0.012)$ & $(0.011)$ & $(0.011)$ & & \\
\hline \multirow[t]{2}{*}{$(\text { Correlation })_{i j}$} & $2.247^{* * *}$ & $1.946^{* * *}$ & 0.285 & 0.338 & & \\
\hline & $(0.470)$ & $(0.510)$ & $(0.538)$ & $(0.550)$ & & \\
\hline Country fixed effects & No & No & Yes & Yes & Yes & Yes \\
\hline $\mathrm{N}$ & 824 & 824 & 824 & 824 & 1,628 & 1,827 \\
\hline $\mathrm{L}$ & 16 & 16 & 16 & 16 & 17 & 17 \\
\hline B & 62 & 62 & 62 & 62 & 175 & 178 \\
\hline$R^{2}$ & 0.69 & 0.70 & 0.86 & 0.86 & 0.85 & 0.94 \\
\hline Estimator & OLS & OLS & OLS & OLS & OLS & Poisson \\
\hline
\end{tabular}

Columns (1)-(5) are estimated by OLS. Column (6) is estimated by the Poisson estimator. Standard errors are clustered at the borrowing country level. $N, L$ and $B$ denote number of observations, number of lending countries and number of borrowing countries. Columns (1) and (2) include in addition the following country specific variables that are not reported: the $\log$ of GDP of countries $i$ and $j$, the average stock return of country $j$, a dummy if country $j$ is a tax haven and corruption dummies for countries $i$ and $j$. These variables are dropped out in columns (3)-(6) which include country fixed effects for countries $i$ and $j$. 
Table 2: Skilled versus unskilled migration - OLS and Poisson

\begin{tabular}{lcccc}
\hline Dependent Variable: & $\begin{array}{c}\log (\text { Loans }) \\
(1)\end{array}$ & $\begin{array}{c}\log (\text { Export }) \\
(2)\end{array}$ & $\begin{array}{c}\text { Loans } \\
(3)\end{array}$ & $\begin{array}{c}\text { Export } \\
(4)\end{array}$ \\
\hline $\log ($ Skilled $)$ & $0.217^{* * *}$ & $0.072^{* *}$ & $0.232^{* * *}$ & 0.087 \\
& $(0.066)$ & $(0.035)$ & $(0.090)$ & $(0.058)$ \\
$\log ($ Unskilled $)$ & -0.033 & $0.084^{* *}$ & 0.001 & $0.119^{* *}$ \\
& $(0.054)$ & $(0.033)$ & $(0.069)$ & $(0.056)$ \\
$\log ($ Distance $)$ & $-0.736^{* * *}$ & $-0.815^{* * *}$ & $-0.258^{* * *}$ & $-0.633^{* * *}$ \\
& $(0.112)$ & $(0.063)$ & $(0.051)$ & $(0.051)$ \\
$\mathrm{N}$ & 1,427 & 1,427 & 1,546 & 1,546 \\
$\mathrm{~L}$ & 17 & 17 & 17 & 17 \\
$\mathrm{~B}$ & 158 & 158 & 157 & 157 \\
$R^{2}$ & 0.86 & 0.93 & 0.94 & 0.97 \\
Estimator & OLS & OLS & Poisson & Poisson \\
\hline
\end{tabular}

Columns (1) and (3) estimate the impact of migration on loans, whereas columns (2) and (4) estimate the impact on trade. The table presents the OLS estimator and the Poisson estimator. Standard errors are clustered at the borrowing country level. $N, L$ and $B$ denote number of observations, number of lending countries and number of borrowing countries, respectively. All columns include country fixed effects, colonial link, language and legal origin as additional controls. 
Table 3: Comparison between culturally closer/more distant countries (OLS results)

\begin{tabular}{|c|c|c|c|c|}
\hline & (1) & $(2)$ & $(3)$ & (4) \\
\hline \multicolumn{5}{|c|}{ Dependent Variable: $\log ($ Loans $)$} \\
\hline $\log _{\text {Migration }_{i j}}$ & $0.155^{* * *}$ & $0.162^{* * *}$ & $0.137^{* * *}$ & $0.137^{* * *}$ \\
\hline & $(0.038)$ & $(0.037)$ & $(0.043)$ & $(0.041)$ \\
\hline $\log _{\text {Migration }_{i j}} *$ Language $_{i j}$ & $\begin{array}{c}-0.171^{* * *} \\
(0.051)\end{array}$ & & & $\begin{array}{c}-0.177^{* * *} \\
(0.058)\end{array}$ \\
\hline $\log$ Migration $_{i j} *$ Colonizer $_{i j}$ & & $\begin{array}{c}-0.165^{* *} \\
(0.071)\end{array}$ & & $\begin{array}{c}-0.101 \\
(0.078)\end{array}$ \\
\hline $\log$ Migration $_{i j} * \operatorname{Legal}_{i j}$ & & & $\begin{array}{c}0.024 \\
(0.037)\end{array}$ & $\begin{array}{c}0.083^{* *} \\
(0.039)\end{array}$ \\
\hline $\log$ Distance $_{i j}$ & $\begin{array}{c}-0.745^{* * *} \\
(0.109) \\
\end{array}$ & $\begin{array}{c}-0.695^{* * *} \\
(0.114) \\
\end{array}$ & $\begin{array}{c}-0.723^{* * *} \\
(0.114) \\
\end{array}$ & $\begin{array}{c}-0.732^{* * *} \\
(0.113) \\
\end{array}$ \\
\hline \multicolumn{5}{|c|}{ Dependent Variable: $\log$ (Export) } \\
\hline $\log _{\text {Migration }_{i j}}$ & $\begin{array}{l}0.160^{* * *} \\
(0.022)\end{array}$ & $\begin{array}{l}0.170^{* * *} \\
(0.022)\end{array}$ & $\begin{array}{l}0.165^{* * *} \\
(0.023)\end{array}$ & $\begin{array}{l}0.174^{* * *} \\
(0.022)\end{array}$ \\
\hline $\log _{\text {Migration }_{i j}} *$ Language $_{i j}$ & $\begin{array}{c}-0.033 \\
(0.034)\end{array}$ & & & $\begin{array}{c}0.018 \\
(0.038)\end{array}$ \\
\hline $\log$ Migration $_{i j} *$ Colonizer $_{i j}$ & & $\begin{array}{c}-0.121^{* * *} \\
(0.040)\end{array}$ & & $\begin{array}{c}-0.126^{* * *} \\
(0.041)\end{array}$ \\
\hline $\log$ Migration $_{i j} *$ Legal $_{i j}$ & & & $\begin{array}{c}-0.022 \\
(0.022)\end{array}$ & $\begin{array}{c}-0.012 \\
(0.025)\end{array}$ \\
\hline $\log$ Distance $_{i j}$ & $-0.800^{* * *}$ & $-0.776^{* * *}$ & $-0.795^{* * *}$ & $-0.772^{* * *}$ \\
\hline$R^{2}$ & 0.86 & 0.86 & 0.86 & 0.86 \\
\hline Obs. & 1,451 & 1,451 & 1,451 & 1,451 \\
\hline No. of Lending Countries & 17 & 17 & 17 & 17 \\
\hline No. of Borrowing Countries & 158 & 158 & 158 & 158 \\
\hline Estimator & OLS & OLS & OLS & OLS \\
\hline
\end{tabular}

This table reports the OLS estimates of the differential effect of migration on loans across country pairs with different cultural proximity, measured by: (1) common language, (2) common colonizer (3) common legal origin. Standard errors are clustered at the borrowing country level. $N, L$ and $B$ denote number of observations, number of lending countries and number of borrowing countries, respectively. All columns include country fixed effects, colonial link, language and legal origin as additional controls. 
Table 4: Comparison between culturally closer/more distant countries (Poisson results)

\begin{tabular}{|c|c|c|c|c|}
\hline & (1) & $(2)$ & (3) & (4) \\
\hline \multicolumn{5}{|c|}{ Dependent Variable: Loans } \\
\hline $\log$ (Migration) & $\begin{array}{l}0.190^{* * *} \\
(0.028)\end{array}$ & $\begin{array}{l}0.203^{* * *} \\
(0.030)\end{array}$ & $\begin{array}{l}0.217^{* * *} \\
(0.029)\end{array}$ & $\begin{array}{l}0.200^{* * *} \\
(0.030)\end{array}$ \\
\hline $\log (\text { Migration })^{*}$ Language & $\begin{array}{c}-0.323^{* * *} \\
(0.081)\end{array}$ & & & $\begin{array}{c}-0.269^{* * *} \\
(0.100)\end{array}$ \\
\hline $\log (\text { Migration })^{*}$ Colonizer & & $\begin{array}{c}-0.278^{* * *} \\
(0.098)\end{array}$ & & $\begin{array}{c}-0.133 \\
(0.114)\end{array}$ \\
\hline $\log (\text { Migration })^{*}$ Legal & & & $\begin{array}{c}-0.118^{* *} \\
(0.056)\end{array}$ & $\begin{array}{c}-0.004 \\
(0.053)\end{array}$ \\
\hline $\log ($ Distance $)$ & $\begin{array}{c}-0.281^{* * *} \\
(0.051)\end{array}$ & $\begin{array}{c}-0.205^{* * *} \\
(0.045)\end{array}$ & $\begin{array}{c}-0.257^{* * *} \\
(0.046)\end{array}$ & $\begin{array}{c}-0.254^{* * *} \\
(0.058)\end{array}$ \\
\hline$R^{2}$ & 0.94 & 0.94 & 0.94 & 0.94 \\
\hline \multicolumn{5}{|c|}{ Dependent Variable: Export } \\
\hline $\log$ (Migration) & $\begin{array}{l}0.200^{* * *} \\
(0.034)\end{array}$ & $\begin{array}{l}0.203^{* * *} \\
(0.034)\end{array}$ & $\begin{array}{l}0.203^{* * *} \\
(0.037)\end{array}$ & $\begin{array}{l}0.208^{* * *} \\
(0.038)\end{array}$ \\
\hline $\log (\text { Migration })^{*}$ Language & $\begin{array}{c}0.033 \\
(0.049)\end{array}$ & & & $\begin{array}{c}0.076 \\
(0.080)\end{array}$ \\
\hline $\log (\text { Migration })^{*}$ Colonizer & & $\begin{array}{c}-0.054 \\
(0.076)\end{array}$ & & $\begin{array}{c}-0.082 \\
(0.084)\end{array}$ \\
\hline $\log (\text { Migration })^{*}$ Legal & & & $\begin{array}{c}-0.009 \\
(0.038)\end{array}$ & $\begin{array}{c}-0.017 \\
(0.040)\end{array}$ \\
\hline $\log ($ Distance $)$ & $\begin{array}{c}-0.628^{* * *} \\
(0.052)\end{array}$ & $\begin{array}{c}-0.628^{* * *} \\
(0.052)\end{array}$ & $\begin{array}{c}-0.633^{* * *} \\
(0.049)\end{array}$ & $\begin{array}{c}-0.618^{* * *} \\
(0.055)\end{array}$ \\
\hline$R^{2}$ & 0.97 & 0.97 & 0.97 & 0.97 \\
\hline $\mathrm{N}$ & 1,588 & 1,588 & 1,588 & 1,588 \\
\hline $\mathrm{L}$ & 17 & 17 & 17 & 17 \\
\hline $\mathrm{B}$ & 158 & 158 & 158 & 158 \\
\hline Estimator & Poisson & Poisson & Poisson & Poisson \\
\hline
\end{tabular}

This table reports the Poisson estimates of the differential effect of migration on loans and exports across country pairs with different cultural proximity, measured by: (1) common language, (2) common colonizer (3) common legal origin. Standard errors are clustered at the borrowing country level. $N, L$ and $B$ denote number of observations, number of lending countries and number of borrowing countries, respectively. All columns include country fixed effects, colonial link, language and legal origin as additional controls. 
Table 5: Summary statistics of long term and short term bonds by issuer type - ECB data

\begin{tabular}{ccccc}
\hline & Total & Financials & Non-Financials & Government \\
\hline & EUR bn & \multicolumn{3}{c}{ ratios of total } \\
Short term & 1,599 & .505 & .049 & .445 \\
Long term & 14,924 & .536 & .053 & .411 \\
\hline
\end{tabular}

Data refers to outstanding bonds issued by residents in the Euro area, as of 2011. Source: ECB, Monthly Bulletin, April 2013.

Table 6: Long term versus short term bonds - OLS and Poisson

\begin{tabular}{lcccc}
\hline Dependent variables: & $\begin{array}{c}\log (\text { Long bonds }) \\
(1)\end{array}$ & $\begin{array}{c}\log \text { (Short bonds }) \\
(2)\end{array}$ & $\begin{array}{c}\text { Long bonds } \\
(3)\end{array}$ & $\begin{array}{c}\text { Short bonds } \\
(4)\end{array}$ \\
\hline $\log$ (Migration) & $0.164^{* *}$ & 0.073 & $0.147^{* * *}$ & 0.108 \\
& $(0.072)$ & $(0.095)$ & $(0.030)$ & $(0.069)$ \\
$\log ($ Distance $)$ & $-0.446^{* * *}$ & $-0.812^{* * *}$ & $-0.304^{* * *}$ & -0.114 \\
& $(0.106)$ & $(0.134)$ & $(0.071)$ & $(0.082)$ \\
$\mathrm{N}$ & 541 & 541 & 1,517 & 1,517 \\
$\mathrm{~L}$ & 31 & 31 & 31 & 31 \\
$\mathrm{~B}$ & 85 & 85 & 92 & 92 \\
$R^{2}$ & 0.90 & 0.74 & 0.95 & 0.94 \\
Estimator & OLS & OLS & Poisson & Poisson \\
\hline
\end{tabular}

This table estimates the effect of migration on investment in long term bonds and short term bonds. $N, L$ and $B$ denote number of observations, number of lending (investing) countries and number of borrowing (issuing) countries, respectively. Regressions are estimated by OLS and Poisson. Standard errors are clustered at the borrowing country level. All columns include country fixed effects, colonial link, language and legal origin as additional controls. 
Table 7: Comparison between Developed and non-Developed countries - OLS and Poisson

\begin{tabular}{lcc}
\hline Dependent variables: & $\begin{array}{c}\log (\text { Loans }) \\
(1)\end{array}$ & $\begin{array}{c}\text { Loans } \\
(2)\end{array}$ \\
\hline $\log$ Migration $_{i j}$ & $0.100^{* *}$ & $0.125^{* * *}$ \\
& $(0.047)$ & $(0.038)$ \\
$\log$ Migration $_{i j} *{\text { (Non-Developed Country })_{j}}$ & 0.058 & $0.145^{* * *}$ \\
& $(0.042)$ & $(0.038)$ \\
$\log$ Distance $_{i j}$ & $-0.744^{* * *}$ & $-0.265^{* * *}$ \\
& $(0.110)$ & $(0.050)$ \\
Obs. & 1,451 & 1,588 \\
Obs with Developed Borrowing Countries & 427 & 431 \\
No. of Lending Countries & 17 & 17 \\
No. of Borrowing Countries & 158 & 158 \\
$R^{2}$ & 0.86 & 0.94 \\
Estimator & OLS & Poisson \\
\hline
\end{tabular}

This table estimates the effect of migration on loans with interaction with non-developed countries. $N, L$ and $B$ denote number of observations, number of lending (investing) countries and number of borrowing (issuing) countries, respectively. Regressions are estimated by OLS and Poisson. Standard errors are clustered at the borrowing country level. All columns include country fixed effects, colonial link, language and legal origin as additional controls. 
Table 8: Long versus Short Bonds, Developed versus non-Developed countries - OLS and Poisson

\begin{tabular}{lcccc}
\hline Dependent variables: & $\begin{array}{c}\log (\text { Long bonds }) \\
(1)\end{array}$ & $\begin{array}{c}\log (\text { Short bonds }) \\
(2)\end{array}$ & $\begin{array}{c}\text { Long bonds } \\
(3)\end{array}$ & $\begin{array}{c}\text { Short bonds } \\
(4)\end{array}$ \\
\hline $\log ^{\text {Migration }} i j$ & $0.198^{* *}$ & 0.108 & $0.299^{* * *}$ & 0.128 \\
& $(0.092)$ & $(0.126)$ & $(0.045)$ & $(0.080)$ \\
$\log$ Migration $_{i j} *{\text { (Non-Developed Country })_{j}}$ & 0.051 & 0.053 & $0.178^{* * *}$ & 0.022 \\
& $(0.071)$ & $(0.123)$ & $(0.035)$ & $(0.053)$ \\
$\log$ Distance $_{i j}$ & $-0.443^{* * *}$ & $-0.809^{* * *}$ & $-0.308^{* * *}$ & -0.113 \\
& $(0.108)$ & $(0.133)$ & $(0.077)$ & $(0.081)$ \\
Obs. & 541 & 541 & 1,517 & 1,517 \\
Obs with Developed Borrowing Countries & 395 & 395 & 643 & 643 \\
No. of Lending Countries & 31 & 31 & 32 & 32 \\
No. of Borrowing Countries & 85 & 85 & 92 & 92 \\
$R^{2}$ & 0.90 & 0.74 & 0.95 & 0.94 \\
Estimator & OLS & OLS & Poisson & Poisson \\
\hline
\end{tabular}

This table estimates the effect of migration on investment in long term bonds and short term bonds, with interaction with non-developed countries. $N, L$ and $B$ denote number of observations, number of lending (investing) countries and number of borrowing (issuing) countries, respectively. Regressions are estimated by OLS and Poisson. Standard errors are clustered at the borrowing country level. All columns include country fixed effects, colonial link, language and legal origin as additional controls. 
Table 9: Country Sample - General

\begin{tabular}{|c|c|c|c|c|c|c|c|}
\hline \multirow{2}{*}{$\begin{array}{l}\text { Lending countries } \\
\text { Austria }(73)\end{array}$} & \multicolumn{7}{|c|}{ Borrowing countries } \\
\hline & Afghanistan (3) & Cambodia (5) & Eq. Guinea (3) & Ireland (15) & Mali (7) & Poland (13) & Switzerland (15) \\
\hline Belgium (134) & Albania (6) & Cameroon (9) & Estonia (11) & Israel (12) & Malta (10) & Portugal (13) & Syria (7) \\
\hline Canada (40) & Algeria (13) & Canada (15) & Ethiopia (9) & Italy (16) & Mauritania (6) & Qatar (7) & Taiwan (10) \\
\hline Denmark (16) & Angola (9) & Cape Verde (3) & Fiji $(4)$ & Jamaica (8) & Mauritius (8) & Romania (14) & Tajikistan (6) \\
\hline Finland (82) & Argentina (15) & Central Africa (3) & Finland (14) & Japan (15) & Mexico (15) & Russia (15) & Tanzania (8) \\
\hline France (164) & Armenia (5) & Chad (2) & France (16) & Jordan (11) & Moldova (6) & Rwanda (6) & Thailand (15) \\
\hline Germany (131) & Australia (16) & Chile (14) & Gabon $(7)$ & Kazakhstan (11) & Mongolia (2) & Samoa (4) & Togo $(6)$ \\
\hline Italy (103) & Austria (15) & China: Mainland (15) & Gambia (4) & Kenya (10) & Morocco (13) & Sao Tome (3) & Tonga (2) \\
\hline Japan (33) & Azerbaijan (7) & China: Hong Kong (7) & Georgia (8) & Korea (15) & Mozambique (8) & Saudi Arabia (13) & Trinidad and Tob. (6) \\
\hline Netherlands (155) & Bahamas (9) & Colombia (14) & Germany (16) & Kuwait (8) & Myanmar (7) & Senegal (9) & Tunisia (13) \\
\hline Portugal (66) & Bahrain (7) & Comoros $(2)$ & Ghana (11) & Kyrgyz Rep. (6) & Namibia (4) & Seychelles (6) & Turkey (13) \\
\hline Spain (91) & Bangladesh (8) & Congo, Dem (7) & Greece (14) & Lao Dem.Rep (5) & Nepal (8) & Sierra Leone (5) & Turkmenistan (6) \\
\hline Sweden (70) & Barbados (7) & Congo, Rep. (8) & Grenada (5) & Latvia (11) & Netherlands (14) & Singapore (13) & Uganda (8) \\
\hline Switzerland (145) & Belarus (9) & Costa Rica (9) & Guatemala (11) & Lebanon (12) & New Zealand (15) & Slovak Rep. (12) & Ukraine (11) \\
\hline \multirow[t]{11}{*}{ Turkey (25) } & Belgium (15) & Croatia (12) & Guinea (7) & Lesotho (5) & Nicaragua (8) & Slovenia (13) & U. A. Emirates (7) \\
\hline & Belize (7) & Cuba (9) & Guinea-Bissau (3) & Liberia (12) & Niger (7) & Somalia (2) & UK (16) \\
\hline & Benin (7) & Cyprus (11) & Guyana (5) & Libya (6) & Nigeria (12) & South Africa (13) & US (16) \\
\hline & Bolivia (10) & Czech Republic (13) & Haiti (5) & Lithuania (12) & Norway (15) & Spain (15) & Uruguay (11) \\
\hline & Bosnia (12) & Cote dIvoire (9) & Honduras (9) & Luxembourg (14) & Oman (6) & Sri Lanka (11) & Uzbekistan (9) \\
\hline & Botswana (4) & Denmark (14) & Hungary (13) & Macau SAR (6) & Pakistan (14) & St. Lucia (2) & Vanuatu (2) \\
\hline & Brazil (15) & Dominica (3) & Iceland (13) & Macedonia, Fyr (10) & Panama (11) & St. Vincent G. (4) & Venezuela (11) \\
\hline & Brunei (5) & Dominican Rep. (9) & India (15) & Madagascar (6) & Papua N. Guinea (6) & Sudan (8) & Vietnam (12) \\
\hline & Bulgaria (14) & Ecuador (9) & Indonesia (14) & Malawi (5) & Paraguay (8) & Suriname (4) & Yemen (6) \\
\hline & Burkina Faso (5) & Egypt (13) & Iran (13) & Malaysia (12) & Peru (14) & Swaziland (3) & Zambia (6) \\
\hline & Burundi (4) & El Salvador (8) & $\operatorname{Iraq}(12)$ & Maldives (3) & Philippines (14) & Sweden (14) & Zimbabwe (8) \\
\hline
\end{tabular}

This table presents the country sample of the regression in Table 1, Column (5). The other OLS regressions use subsets of this sample, depending on missing data. Poisson regressions may include few more borrowing countries due to the inclusion of zero values. The sample of Table 6 is different and presented in Table 10. The parentheses show the number of observations where the country is a lending country (the left column) or a borrowing country (the other columns). For example, the US is a lender in 145 observations and a borrower in 16 observations. Since the number of lending countries is much smaller than the number of borrowing countries, a lending country lends to many borrowers but a borrowing country borrows from few lenders in this sample. 
Table 10: Country Sample for Bond Regression

\begin{tabular}{|c|c|c|c|}
\hline \multicolumn{2}{|l|}{ Lending countries } & \multicolumn{2}{|l|}{ Borrowing countries } \\
\hline Australia (90) & Argentina (19) & Greece (16) & Pakistan (16) \\
\hline Austria (61) & Australia (23) & Guatemala (12) & Panama (12) \\
\hline Belgium (88) & Austria (20) & Honduras (11) & Peru (16) \\
\hline Brazil (13) & Bahamas, The (8) & China: Hong Kong (11) & Philippines (18) \\
\hline Canada (14) & Bahrain (6) & Hungary (17) & Poland (17) \\
\hline Chile (34) & Bangladesh (14) & Iceland (14) & Portugal (19) \\
\hline Czech Republic (69) & Belgium (22) & India (18) & Qatar (5) \\
\hline Denmark $(85)$ & Bolivia (14) & Indonesia (17) & Romania (18) \\
\hline Finland (22) & Bosnia and Herzegovina (15) & $\operatorname{Iran}(15)$ & Russian Federation (20) \\
\hline France (89) & Botswana (7) & Ireland (21) & Saudi Arabia (9) \\
\hline Germany (81) & Brazil (19) & Israel (16) & Senegal (11) \\
\hline Greece (5) & Bulgaria (15) & Italy (25) & Singapore (14) \\
\hline Hungary (5) & Cote d'Ivoire (12) & Jamaica (12) & Slovak Republic (17) \\
\hline Iceland (5) & Canada $(23)$ & Japan (21) & Slovenia (14) \\
\hline Ireland (33) & Chile (15) & Jordan (14) & South Africa (15) \\
\hline Italy $(76)$ & China (20) & Kazakhstan (14) & Spain $(24)$ \\
\hline Japan (30) & Colombia (15) & Kenya (13) & Sweden (23) \\
\hline Korea, Rep. (17) & Costa Rica (13) & Korea, Rep. (17) & Switzerland (22) \\
\hline Luxembourg (78) & Croatia (16) & Lebanon (16) & Taiwan (13) \\
\hline Netherlands (89) & Cyprus (13) & Luxembourg (18) & Thailand (17) \\
\hline New Zealand (41) & Czech Republic (16) & Malaysia (16) & Trinidad and Tobago (12) \\
\hline Norway (83) & Denmark (19) & Malta (13) & Tunisia (15) \\
\hline Poland (32) & Ecuador (14) & Mexico (18) & Turkey (19) \\
\hline Portugal (14) & Egypt, Arab Rep. (14) & Morocco (15) & Ukraine (16) \\
\hline Slovak Republic (3) & El Salvador (11) & Namibia (10) & United Arab Emirates (7) \\
\hline South Africa (7) & Estonia (14) & Netherlands (23) & United Kingdom (28) \\
\hline Spain (22) & Finland (20) & New Zealand (17) & United States (29) \\
\hline Sweden (14) & France $(27)$ & Nicaragua (12) & Uruguay (15) \\
\hline Switzerland (89) & Georgia (12) & Nigeria (15) & Venezuela, RB (13) \\
\hline Turkey (4) & Germany (27) & Norway (20) & Vietnam (16) \\
\hline United Kingdom (89) & & & Zimbabwe (13) \\
\hline United States (81) & & & \\
\hline
\end{tabular}

This table presents the country sample of Table 6 , which includes zero values of the dependent variable. The sample of the OLS regressions does not include the zero values. The parentheses show the number of observations where the country is a lending country (the left column) or a borrowing country (the other columns). 